\title{
CHARACTERIZATION OF THE ASHES FROM THE 2014-2015 TURRIALBA VOLCANO ERUPTIONS BY MEANS OF SCANNING ELECTRON MICROSCOPY AND ENERGY DISPERSIVE $X$-RAY SPECTROSCOPY
}

\author{
CARACTERIZACIÓN DE LAS CENIZAS DE LAS ERUPCIONES DEL \\ VOLCÁN TURRIALBA EN 2014 Y 2015 POR MEDIO DE MICROSCOPÍA \\ ELECTRÓNICA DE BARRIDO Y ESPECTROSCOPÍA DE RAYOS-X POR \\ ENERGÍA DISPERSIVA
}

\author{
Oscar H. Lücke \& Ariadna Calderón* \\ University of Costa Rica, P.O. Box 214-2060, San Pedro, Costa Rica \\ *Autor para contacto: aricmesen@gmail.com
}

(Recibido: 30/11/2015; aceptado: 3/02/2016)

\begin{abstract}
The Turrialba Volcano is a stratovolcano located approximately $35 \mathrm{~km}$ northwest from San José, Costa Rica's capital city. Since October 29, 2014, until at least late 2015, a series of eruptions has represented the most significant activity of this volcano since the 1860s. These eruptions dispersed a significant volume of ash that reached the most populous areas of the country. In this article, the characteristics of the ash particles are analyzed in order to establish the nature of the eruptive events that occurred on 2014 and 2015, and to monitor the evolution of the eruptive processes. The analysis was carried out utilizing optical microscopy and stereomicroscopy techniques, as well as novel scanning electron microscopy (SEM) methods that involve imaging and element composition analysis by means of Energy Dispersive X-Ray Spectroscopy (EDX). Results show the evolution of the Turrialba eruptions from phreatic events in 2014, with ashes composed entirely of non-juvenile fragments, to phreatomagmatic events starting on March 12,2015 with the appearance of a significant fraction of juvenile components in the ash.

Keywords: Volcanic Ash, Scanning Electron Microscope, X-Ray Spectroscopy, Phreatic Eruption, Phreatomagmatic Eruption, Turrialba Volcano.
\end{abstract}

RESUMEN: El volcán Turrialba es un estratovolcán localizado aproximadamente $35 \mathrm{~km}$ al noroeste de San José, la ciudad capital de Costa Rica. Desde el 29 de octubre de 2014, hasta al menos el fin del año 2015, el volcán mostró una serie de erupciones que representan su actividad más significativa desde la década de los 1860s. Estas erupciones dispersaron un volumen significativo de cenizas, las cuales alcanzaron las áreas más pobladas del país. En este artículo, se analizan las características de las partículas de ceniza con el fin de establecer el tipo de erupciones que ocurrieron en 2014 y 2015, así como monitorear la evolución de los procesos eruptivos. El análisis se llevó a cabo mediante las

LÜCKE, O. H. \& CALDERÓN, A., 2016: Characterization of the ashes from the 2014-2015 Turrialba Volcano Eruptions by means of Scanning Elecron Microscopy and Energy Dispersive X-Ray Spectroscopy.- Rev. Geol. Amér. Central, 54: 109-123, DOI: $10.15517 /$ rgac.v54i0.23281 
técnicas de microscopía y estereoscopía óptica, así como técnicas novedosas de microscopía electrónica de barrido (MEB), que involucran la adquisición de imágenes y el análisis de composición elemental por medio de espectroscopía de rayos-x por energía dispersiva (EDX). Los resultados muestran la evolución de las erupciones del volcán Turrialba desde eventos freáticos en 2014, con cenizas compuestas en su totalidad por partículas no-juveniles, hacia eventos freato-magmáticos, comenzando en marzo de 2015 con la presencia de una fracción apreciable de componentes juveniles en la ceniza.

Palabras clave: Ceniza volcánica, microscopía electrónica de barrido, espectroscopía de rayos-x, erupción freática, erupción freatomagmática, volcán Turrialba.

\section{INTRODUCTION}

Since October 29, 2014 and until the date of submission of this article, the Turrialba volcano has manifested a series of eruptions that has dispersed ashes across central Costa Rica. These are the most significant eruptions in a cycle of increased activity that started in 2007 with significant changes in seismicity and fumarolic activity (Soto \& Mora, 2012). The last eruptive period prior to 2007 dates back to between 1864 and 1886, when historical records indicate the occurrence of Vulcanian and Strombolian eruptions (Ruíz, 2012). The recent activity of the Turrialba volcano has a direct impact in the lives of nearly half of the population of Costa Rica, since the path of dispersion of ashes and gas from Turrialba according to Soto \& Mora (2012) covers the most populous region of the country, known as the Greater Metropolitan Area. This region has a population of 2.27 million people (INEC, 2011) concentrated on $1967 \mathrm{~km}^{2}$.

Since October 2014, the Turrialba volcano maintained a high level of seismic activity. It showed increased exhalative activity, interrupted by short periods of decreased degassing and sporadic eruptions with local dispersion of ash, lapilli and blocks. On March 8, 2015, a new eruptive phase started, with more frequent ash eruptions that culminated with three larger eruptions on March 12: the first at 10:53 (local time, UTC-6 hours), 25 minutes long; the second at 13:38, 48 minutes long; and the last one at 14:39 (Fig. 1), 35 minutes long [M. Mora, written comm.], all durations based on seismic signal records. Figure 1 shows the seismological record of the 14:49 (20:49 UTC) eruption as recorded at the seismological station CVTR of the National Seismological Network (Red Sismológica Nacional, RSN), located on the Turrialba's upper caldera. The ashes of these eruptions reached the Central Valley and prompted the closure of the International Airport for several hours (Recio, 2015).

Although Turrialba is an active volcano located near densely populated areas, its importance in terms of volcanic hazards has been overshadowed by the presence of other Quaternary volcanoes of the Central Cordillera, specifically Poás and Irazú, that showed notable activity during the second half of the XX century. However, the importance of Turrialba in terms of volcanic hazards must not be underestimated due to its proximity to several cities and towns and the development of agricultural and tourist activities on its slopes, that are key to the local economy.

In this work, the characteristics and composition of the erupted ashes and the evolution of the eruption processes based on analysis by means of optical and Scanning Electron Microscopy (SEM) are studied, as well as their geochemical characterization using Energy Dispersive X-Ray Spectroscopy (EDX).

\section{PREVIOUS WORK}

The recent eruptive history of Turrialba was studied by Reagan et al. (2006), who recognized six explosive periods in the past 3400 years, characterized as small volume phreatic and 

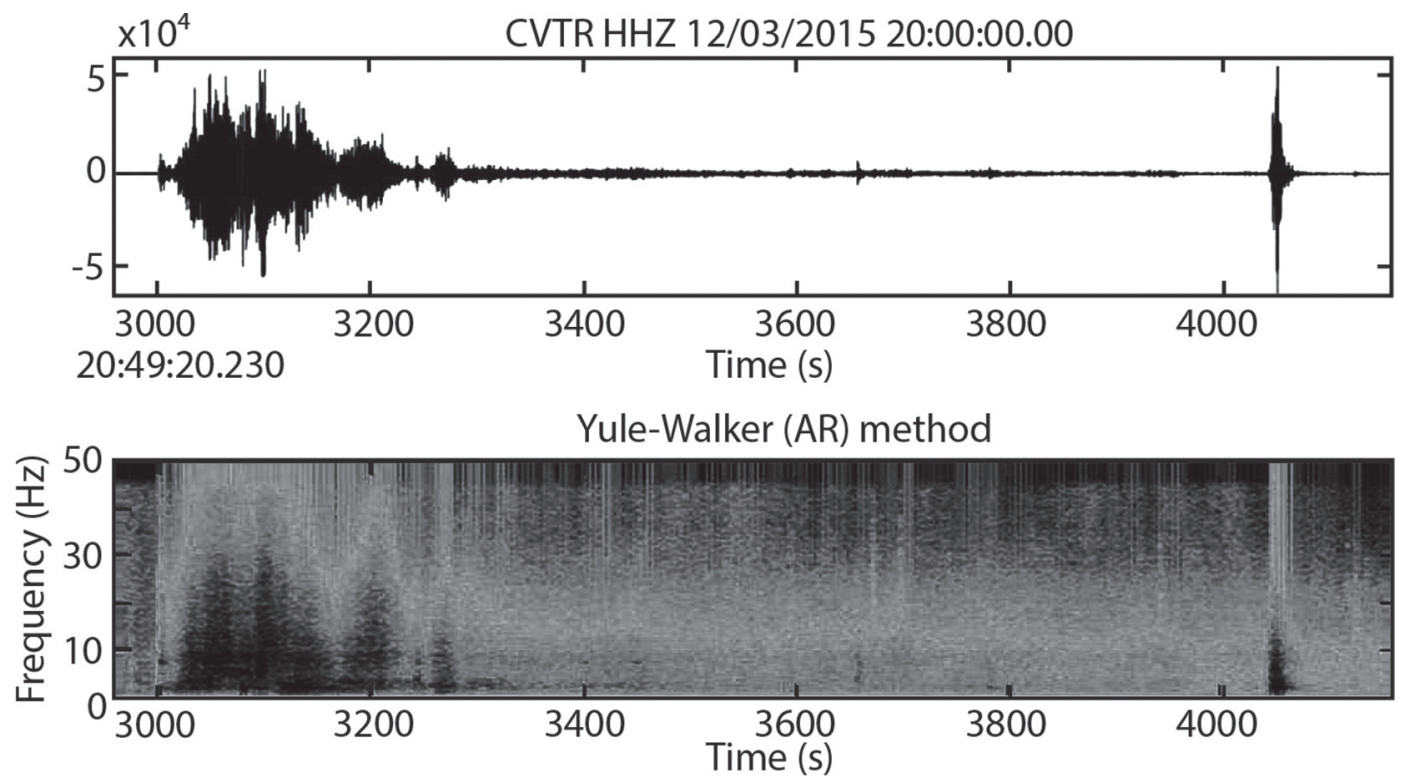

Fig. 1: Seismogram (above) from RSN station CVTR showing the March 12, 2015 eruption at 14:39 local time (20:49, UTC). Frequency spectrogram (below) based on the Yule-Walker method. Source: M. Mora, RSN, written comm., 2015.

phreatomagmatic eruptions. Reagan et al. (2006) pointed out the presence of a layer with Plinian distribution at approximately 1970 years before present. Most of the tephras for this period are of basaltic or basaltic andesite composition, with the exception of a Plinian event, that is composed of silicic andesite. A comprehensive study of depositional and erosional processes on the Turrialba volcano was performed by Ruíz (2012), who focused on the geochronology and geochemistry of lavas from the Paleo- and Neo-Turrialba stages defined by Soto (1988). For this period, Ruíz (2012) identified a wide range in composition of lavas from basalts to dacites, all belonging to the High-K Calk-Alkaline series with silica contents ranging from 52 to $64 \mathrm{wt} . \%$ for lavas erupted in the last $100 \mathrm{ka}$.

Soto \& Mora (2012) provided a summary of the historical activity of Turrialba and analyzed the increase in seismic activity starting in 2007. The authors interpret a change in the dynamics of the volcanic system due to the change from shallow to deeper seismic sources from July to September of that year. Soto \& Mora (2012) also provided volcanic hazard maps that detailed scenarios for ballistic impacts, ash fall, and acid rain.

Regarding the use of Scanning Electron Microscopy tools for the characterization of volcanic ash, Pardo et al. (2014) analyzed glass particles from the August 6 2012, Mount Tongariro eruption in New Zealand and provided criteria to identify juvenile pyroclasts. These authors concluded that the observed glass particles for that particular eruption were originated through mechanical fragmentation of country rock due to the presence of stepped surfaces and their poorly vesicular shape. The authors pointed out that lavas and pyroclastic deposits from earlier eruptions may be recycled by recent eruptions and may preserve some of the structure of juvenile clasts. However, inconsistencies between the physical and chemical properties of the particles may provide criteria for identification of a mixed provenance. Since the interpretation of the origin of the particles based on ash grain morphology could be ambiguous, the distinct glass compositions shared by suspected juvenile particles may provide a link to a common magmatic source. 


\section{METHODS}

\section{Sample Preparation and Selection}

The ash samples were collected within 24 hours of being erupted at locations in close proximity to the vent such as: "La Central", "La Silvia”, "Los Quemados", "La Picada", a bridge on the road leading to "La Picada", and in the immediately adjacent area to the active crater on the volcano's upper caldera (Fig. 2).

The samples were separated for analysis in two batches: coated and clean samples. The coated samples were analyzed as collected, i.e. containing the fine volcanic dust that coated the majority of the coarser grains. The clean samples were rinsed and sifted using No. $60(0.25 \mathrm{~mm}$, for $2 \phi)$, No. $100(0.15 \mathrm{~mm}$, for $2.7 \phi)$, No. $120(0.125$ $\mathrm{mm}$, for $3 \phi)$, No. $200(0.05 \mathrm{~mm}$ for $4.3 \phi)$, and No. $325(0.032 \mathrm{~mm}$, for $5 \phi)$ sieves. The sifted samples were rinsed through several cycles with ultrapure water (UPW) and placed in an ultrasonic bath in order to remove as much dust as possible from the surface of the grains without modifying the grain morphology. The samples for microscopic analysis were left to dry at room temperature.

\section{Optical Microscopy}

For the observation of samples under optical polarizing microscopy, the $5 \phi(0.032 \mathrm{~mm})$ and $2.7 \phi(0.15 \mathrm{~mm})$ fraction of the ash were separated and mounted as smear slides with immersion oil of $n=1.515-1.517$. The slides were observed on a polarizing microscope (Nikon Eclipse LV100N POL) and photographed for image stacking using the software Combine ZP (www.hadleyweb.pwp. blueyonder.co.uk). Coarser fractions from $2.7 \phi$ to $2 \phi(0.15$ to $0.25 \mathrm{~mm})$ were observed under nonpolarized light on a stereo microscope (Nikon SMZ1270) for analysis, photography, and selection for observation under SEM.

Overall, ash grains were separated with the micro stereoscope and classified into: visibly altered lithic fragments, visibly altered free crystals, dark tachylitic scoria, translucent sideromelane,

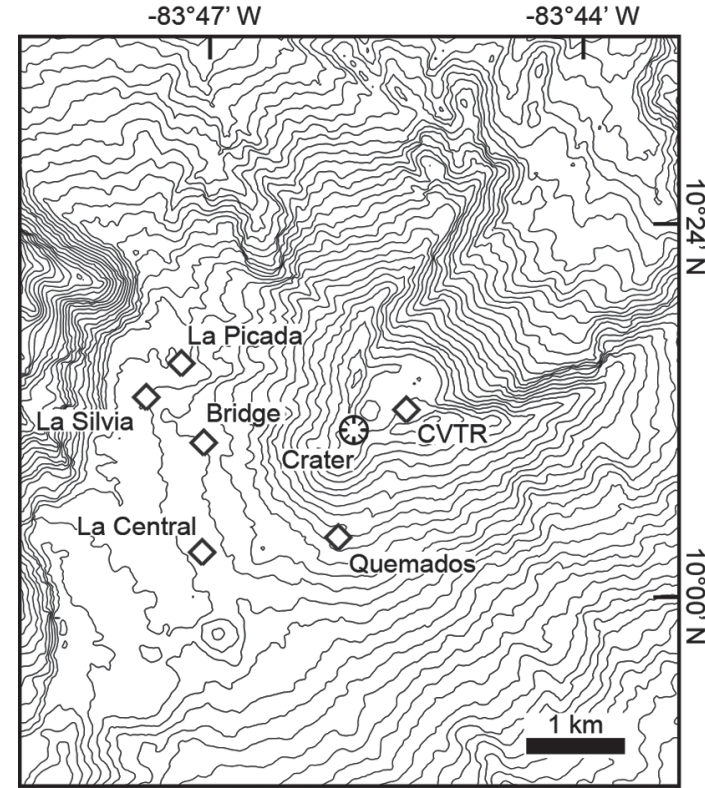

Fig. 2: Collection sites of the ash samples, location of the active crater on Turrialba volcano and location of the seismological station CVTR of the RSN.

and unaltered free crystals. This a priori classification was established in order to select the grains for SEM analysis and was later revised taken into account the SEM and EDX observations. Criteria for classification will be discussed in detail in the results section. Percentages of abundance of different components of the ash were calculated from point counting under the stereo microscope. A minimum of 900 grains were counted for the $2.7 \phi$ fraction of the ash for each eruption.

\section{Scanning Electron Microscopy (SEM) and Energy Dispersive X-Ray Spectroscopy (EDX)}

The individual ash grains were mounted on metallic bases using double sided carbon tape and were left uncoated in order to perform EDX analysis on the surface. Scanning Electron Microscope (SEM) images were obtained for the ash grains using the Model S-3700N SEM at the Microscopic Structures Research Center (Centro de Investigación en Estructuras Microscópicas, CIEMic) of the University of Costa Rica. 
In addition to the SEM imaging, chemical composition analysis was performed using Energy Dispersive X-Ray Spectroscopy (EDX). According to Reed (2006), the energy-dispersive detectors record X-rays of all energy simultaneously and produce a plot of intensity versus X-ray photon energy. Reed (2006), states that the detection efficiency of $\mathrm{X}$-rays reaching the detector is close to $100 \%$ for an energy range below $20 \mathrm{KeV}$. In this study, we focus the EDX analysis on elements within a 0 to $10 \mathrm{KeV}$ energy spectra. The spectra generated by the EDX scan are displayed as histograms in which markers are inserted to show the position of elemental peaks. Once the presence of specific elements is determined by the appearance of such peaks in the spectrum, the quantitative analysis is performed in order to determine the weight percentage concentration of the components of the sample by performing quantitative scanning and by mapping the surface marked by the operator.

\section{Element Mapping and Quantitative Composi- tional Analysis}

According to Reed (2006), mapping is performed by recording X-ray photons for a fixed time on a given point and performing this repeatedly over the scanned area. The information is displayed as a combined map of the surface with different colors illuminating the presence of elements detected by the scan. The scan can be displayed as deconstructed maps of the same surface showing the presence of individual elements using a color legend. Quantitative mapping can be carried out by saving the raw data of absolute X-ray intensities and calculating elemental concentrations from the ratios of the intensities and their comparison with samples of known concentrations. First, spectrograms were obtained for the bulk composition of the grain by scanning the surface. For all grains, an X-ray takeoff angle of $35^{\circ}$ and an accelerating voltage of $15 \mathrm{kV}$ were used to carry out the EDX analysis. The concentration of each element identified on the spectrograms was obtained from the measured intensities and is displayed as weight percentage.
For this study, EDX analysis was able to resolve the presence and concentration of major rock/mineral forming elements such as: $\mathrm{Al}, \mathrm{Ca}$, $\mathrm{Cr}, \mathrm{Fe}, \mathrm{K}, \mathrm{Mg}, \mathrm{Mn}, \mathrm{Na}, \mathrm{P}, \mathrm{S}, \mathrm{Si}$, and Ti. Reed (2006) stated that oxygen (O) can only be detected using a thin-window energy dispersive detector. Thus, for this study, the oxygen concentration was not quantified directly from EDX scans, although the presence of oxygen can be qualitatively interpreted from the spectrogram peaks. In order to interpret geochemical properties of the samples from the concentration of major elements, a stoichiometric conversion from elements to oxides was performed. The geochemical plots were carried out using the IgPet software, from Terra Softa Inc. (Carr, 2014).

\section{RESULTS AND DISCUSSION}

From the point of view of the composition and morphology of ash grains, much of the burden of distinguishing between a purely phreatic event and a phreatomagmatic eruption, lies on determining the presence of juvenile components. This distinction between juvenile and non-juvenile fragments is ambiguous and may lead to misinterpretation, as explained by Pardo et al. (2014). In the following section, results from analysis of ash grain morphology and composition are presented. The presence or absence of juvenile components in ashes erupted on different events are established and the plausible scenarios for characterization of the corresponding eruptions are discussed.

\section{The October-November 2014 Eruptions: Phreatic Events}

Ash particles from the October 29 through November 2, 2014 Turrialba eruption deposit (Fig. 3) show a generalized non-juvenile composition represented by highly altered fragments of pumice, sideromelane, tachylite, and free crystals. Figure $3 \mathrm{~A}$ shows an optical image of a highly altered pumice grain. Note the presence of orange 


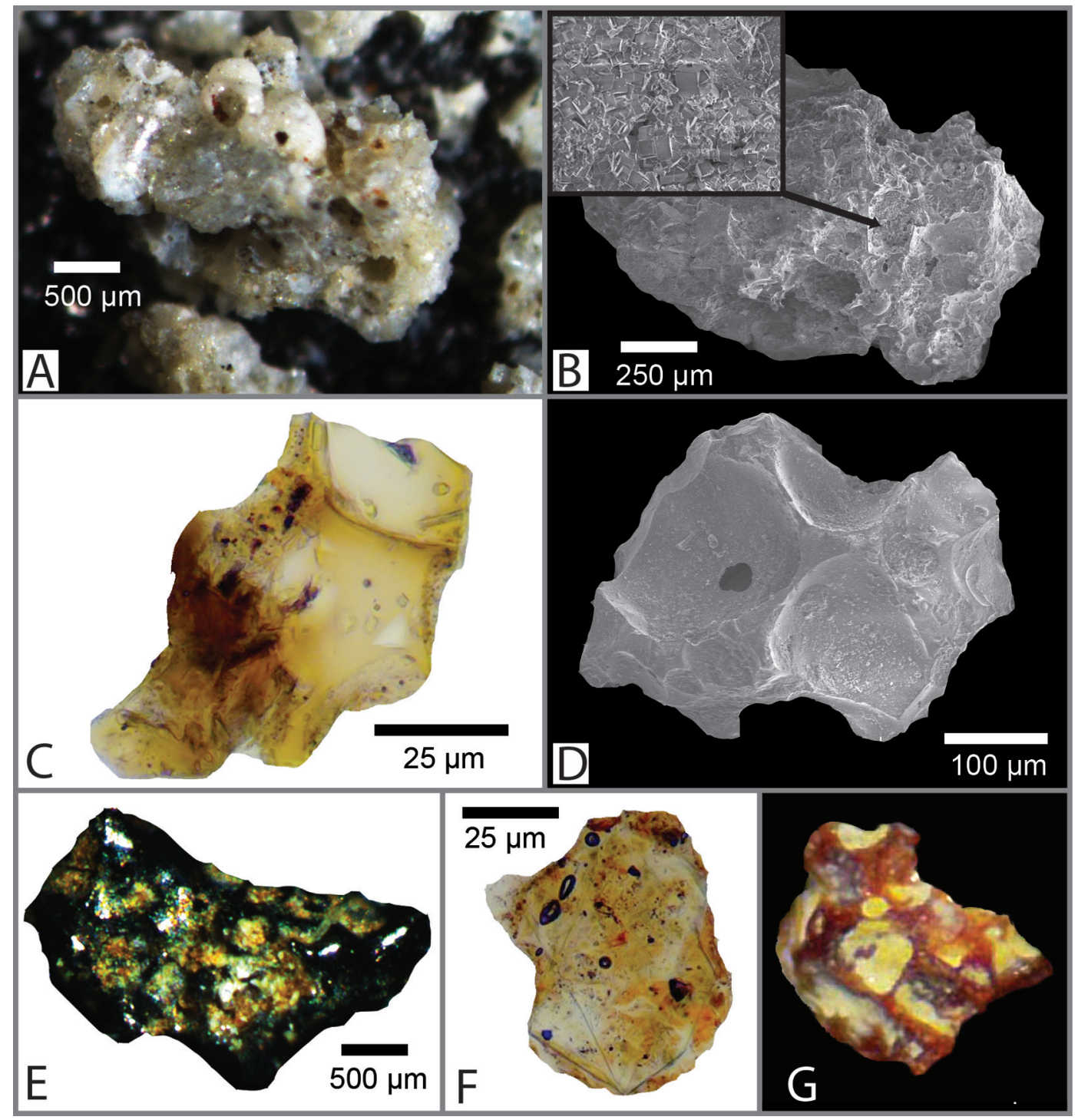

Fig. 3: Ash grains from the October 29 through November 2, 2014 Turrialba eruptions. A) Optical image of a highly altered pumice grain. B) SEM image of the grain in figure 3A, detailed frame shows the structure of the isometric crystals that compound the lithophysae. C) Altered sideromelane grain. D) SEM image of the grain in figure 3C. E) Altered tachylitic scoria with oxidation of the inner surfaces of the vesicles. F) Plagioclase crystals adhered to altered vesiculated sideromelane. G) Altered vesiculated grain.

colored oxides on the outer matrix and the formation of lithophysae with translucent crystals within the vesicles. A closer examination using the scanning electron microscope (Fig 3B) shows the structure of the isometric crystals compounding the lithophysae. The surface of these crystals illuminated the presence of sodium when the elemental mapping was performed. It is interpreted that the crystals forming the lithophysae are zeolites originated by an alteration caused by the volcano's hydrothermal system on previously erupted pumices.

Figure $3 \mathrm{C}$ shows an altered sideromelane grain. Note the rounded edges due to the reworking of the grain. The glass appears altered with a brown/orange surface on the left edge of the 
crystal. The grain, however, conserves some of the morphology of the dividing septa of individual vesicles. This structure can be recognized in the SEM image of the same grain shown in figure 3D. The SEM image shows the inner surface of the vesicles that have a rough, scaly texture. Figure 3D shows a stark contrast to the smooth, highly reflective inner surfaces of the sideromelane grain from the March 12, 2015 eruption shown in figure 4D that will be described later.

Figures $3 \mathrm{E}$ and $3 \mathrm{G}$ show scoria fragments with different degrees of alteration. Figure $3 \mathrm{E}$ is an optical image of an altered tachylitic scoria with oxidation of mafic components of the glass, particularly in the inner surfaces of the vesicles. The outer surface appears clean and vitreous, but inside the vesicles, the glass is altered to an iron rich phyllosilicate or hydroxide. Moreover, the shape of the grain is rounded and the septa dividing the vesicles are flattened to a uniform level. The alteration observed in figure $3 \mathrm{E}$ is interpreted as a product of weathering rather than hydrothermal alteration, since the oxides have formed on the exposed surfaces of the grain but the inner matrix appears unaltered. In contrast to figure $3 \mathrm{E}$, there is the pervasive alteration of the grain --shown in figure 3G-- that shows a similar yellow clay material developing in the inner surfaces of the vesicles, but the matrix has a bright orange color consistent with limonitic hydrothermal alteration of iron rich glass. The alteration in figure $3 \mathrm{G}$ is understood as a product of the interaction of the ash material with the hydrothermal system of the volcano, possibly in the conduit wall. Further evidence of limonitic and argillitic hydrothermal alteration on pre-existing materials that compose the volcanic edifice and crater walls at the Turrialba Volcano was provided by BragadoMassa et al. (2014).

Figure $3 \mathrm{~F}$ shows colorless triclinic twinned (plagioclase) crystals adhered to altered vesiculated sideromelane. Notice the orange specs of oxidation of the glass on the outer surface. The crystals appear unaltered under the optical microscope; however, the glass shows a similar state of alteration as sideromelane shown in figure 3C. Overall, the ashes from the 2014 eruptions show a $\sim 10$ vol.\% of free crystals
( $9 \%$ plagioclase, $1 \%$ olivine). Most crystals are adhered to altered glass and all the free crystals appear altered with cloudy, yellowy appearance in the case of the plagioclase.

In general, the ash from the studied OctoberNovember 2014 eruptions shows no evidence of juvenile components. The products of these eruptions suggest that the 2014 events are akin to the phreatic eruptions of lithic ash that occurred in 2007 and 2010 (Ruíz, 2012). Phreatic eruptions according to Barberi et al. (1992) involve fragmentation created by explosions of steam without the direct involvement of magma. Hence, all ejected materials are fragments of pre-existing rock. Magma however, may be involved in the eruption process as the source of energy for the explosion by heating and flashing when it comes in contact with water from a shallow aquifer (Browne \& Lawless, 2001; Rouwet et al., 2014). It is important to reiterate that in the event of phreatic eruptions, only country rock or overburden is ejected (Browne \& Lawless, 2001). The absence of juvenile fragments in the October-November 2014 eruptions of Turrialba suggests that the fragmentation and dispersion of ash occurred through a phreatic process.

\section{The March 12, 2015 Eruption: A Phreatomagmatic Event}

The ash from the March 12, 2015 eruption differs from the 2014 eruptions in that it shows a $\sim 10$ vol.\% content of unaltered tachylitic scoria, $\sim 7$ vol. $\%$ of unaltered vesiculated sideromelane grains, as well as unaltered olivine (3 vol.\%) and plagioclase (4 vol.\%) free crystals. It is interpreted that these components are juvenile material. Accounting for the free crystals as juvenile material, the $2.7 \phi$ fraction of the ash has $\sim 24$ vol.\% of juvenile grains. In this section, the focus is put on the description of the juvenile grains.

The tachylitic scoria (Fig 4A) appear unaltered and have a porphyritic texture with occasional phenocrysts of unaltered plagioclase imbedded in a black, vitreous matrix. The SEM image of a tachylitic scoria (Fig. 4B) shows the smooth inner surfaces of the vesicles and the angular fractures of the broken septa. 


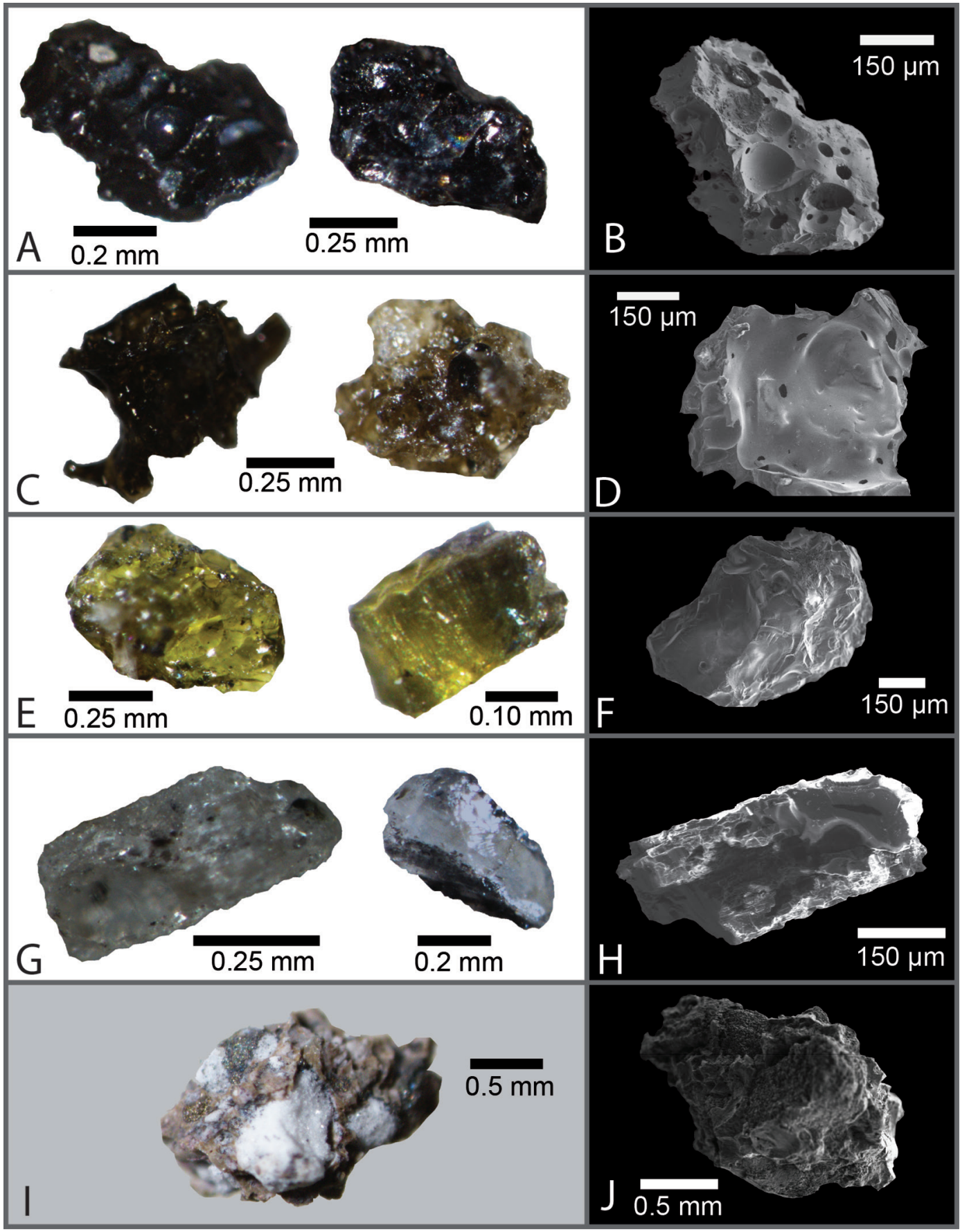

Fig. 4: Ash grains from the March 12, 2015 Turrialba eruption. A) Optical photo of tachylitic scoria. B) SEM image of left grain in figure 4A. C) Vesiculated sideromelane grains. D) SEM image of right grain of figure 4C. E) Optical photo of free crystals of olivine. F) SEM image of the left olivine crystal in figure 4E. G) Optical photo of free crystals of plagioclase. H) SEM image of the left plagioclase crystal in figure 4G. I) Optical photo of an altered lithic grain. J) SEM image of grain shown in figure 4I. 
Table 1

Bulk composition of ash grains from quantitative EDX analysis. All data are in percentage by weight [wt.\%]. Abbreviations on the last column: G.T. (Grain Type); T.S. (Tachylitic Scoria); V.S. (Vesiculated Sideromelane; P.L. (Porphyritic Lithic); P (Pumice); C.P. (Coated Pumice); Ol. (Olivine free crystal); Pl. (Plagioclase free crystal).

\begin{tabular}{ccccccccccccc}
\hline Grain & $\mathrm{SiO}_{2}$ & $\mathrm{TiO}_{2}$ & $\mathrm{Al}_{2} \mathrm{O}_{3}$ & $\mathrm{Fe}_{2} \mathrm{O}_{3}$ & $\mathrm{MnO}$ & $\mathrm{MgO}$ & $\mathrm{CaO}$ & $\mathrm{Na}_{2} \mathrm{O}$ & $\mathrm{K}_{2} \mathrm{O}$ & $\mathrm{P}_{2} \mathrm{O}_{5}$ & $\mathrm{As}_{2} \mathrm{O}_{5}$ & $\mathrm{G}_{\text {.T. }}$ \\
\hline Lmv1 & 57.003 & 1.919 & 16.639 & 10.833 & 0.000 & 2.679 & 6.042 & 2.080 & 2.478 & 0.327 & 0.000 & T.S. \\
$\mathrm{Lmv2}$ & 67.565 & 2.113 & 13.415 & 5.803 & 0.000 & 3.183 & 5.365 & 1.421 & 1.100 & 0.037 & 0.000 & T.S. \\
$\mathrm{Lv1}$ & 78.195 & 5.669 & 10.312 & 2.513 & 0.000 & 0.161 & 1.089 & 1.029 & 1.033 & 0.000 & 0.000 & V.S. \\
$\mathrm{Lc} 2$ & 46.244 & 0.876 & 9.139 & 18.795 & 0.000 & 22.628 & 1.092 & 0.680 & 0.546 & 0.000 & 0.000 & P.L. \\
$\mathrm{Cm} 2$ & 1.769 & 0.000 & 2.404 & 94.309 & 0.770 & 0.649 & 0.000 & 0.099 & 0.000 & 0.000 & 0.000 & T.S. \\
$\mathrm{Cm} 3$ & 52.257 & 1.283 & 15.343 & 17.770 & 0.000 & 4.183 & 5.724 & 1.659 & 1.615 & 0.168 & 0.000 & T.S. \\
$\mathrm{Cf1}$ & 75.929 & 1.056 & 16.575 & 1.954 & 0.000 & 0.000 & 1.110 & 1.421 & 1.838 & 0.116 & 0.000 & P. \\
$\mathrm{Cf2}$ & 88.816 & 0.906 & 4.898 & 1.633 & 0.000 & 0.000 & 2.425 & 0.222 & 0.805 & 0.000 & 0.000 & P. \\
$\mathrm{LSBm} 2$ & 74.366 & 1.465 & 15.719 & 3.293 & 0.000 & 1.032 & 1.337 & 0.759 & 2.029 & 0.000 & 0.000 & P.L. \\
$\mathrm{LQf2} *$ & 86.772 & 0.000 & 11.069 & 0.000 & 0.189 & 0.837 & 0.000 & 0.000 & 0.000 & 0.000 & 0.491 & C.P. \\
$\mathrm{A} 1$ & 64.428 & 0.000 & 18.113 & 4.502 & 0.000 & 1.266 & 6.556 & 2.709 & 2.427 & 0.000 & 0.000 & T.S. \\
$\mathrm{A} 5$ & 58.068 & 2.445 & 15.066 & 9.470 & 0.000 & 3.981 & 6.265 & 2.233 & 2.472 & 0.000 & 0.000 & T.S. \\
$\mathrm{B} 1$ & 61.848 & 1.572 & 14.738 & 8.559 & 0.000 & 2.305 & 5.640 & 2.990 & 2.348 & 0.000 & 0.000 & V.S \\
$\mathrm{C} 1$ & 55.496 & 0.000 & 6.585 & 9.344 & 0.000 & 9.655 & 17.238 & 1.114 & 0.568 & 0.000 & 0.000 & Ol. \\
$\mathrm{D} 1$ & 60.061 & 0.000 & 26.742 & 0.000 & 0.000 & 0.331 & 8.554 & 3.898 & 0.414 & 0.000 & 0.000 & P1. \\
D3 & 62.154 & 0.000 & 26.109 & 0.000 & 0.000 & 0.000 & 7.155 & 4.581 & 0.000 & 0.000 & 0.000 & Pl. \\
\hline
\end{tabular}

*Point analysis on the clay coating

The grains of vesiculated sideromelane (Fig. 4C) have a translucent aspect and show the preservation of vesicular structures and septa. The SEM image (Fig. 4D) of the sideromelane grain shown on figure $4 \mathrm{C}$ (right) shows the smooth surfaces of the vesicle walls and the absence of fractures or exfoliation that contrasts with the scaly aspect of the altered sideromelane of figure 3D. The uncoated glass surface was highly reflective of the electron beam, thus the bright edges of the vesicle walls.

A significant difference of the March 2015 eruptions with the 2014 eruptions is the presence of unaltered free crystals of olivine (Figs. $4 \mathrm{E}$ and $4 \mathrm{~F}$ ) and plagioclase (Figs. $4 \mathrm{G}$ and $4 \mathrm{H}$ ). Ashes from previous eruptions show grains made up mainly of plagioclase crystals but these were adhered to altered glass (Fig. 3F). Moreover, plagioclase crystals from the previous eruptions appeared cloudy and had light yellow colors, whereas a fraction of the March 2015 plagioclase free crystals appears unaltered, as shown in figure 4G. Olivine and plagioclase crystals from the March 2015 eruption are translucent, have a vitreous shine and show no signs of alteration. The plagioclase is prismatic and shows exfoliated surfaces with no signs of re-working (Fig. 4H).

The non-juvenile fragments of the ashes correspond to $\sim 76 \mathrm{vol} . \%$ of the counted grains of the analyzed fraction. The characteristics of the non-juvenile fragments are similar to the grains described for the 2014 eruptions, with presence of altered scoria, altered sideromelane, altered plagioclase crystals, and gypsum. Figure 4I shows an optical photograph of an altered lithic. Observe the presence of pyrite on the surface of the grain and white radial zeolites forming lithophysae in the vesicles. The SEM image of altered lithic shown in figure $4 \mathrm{~J}$ shows the rugose texture of the altered matrix expected for a non-juvenile grain. 


\section{Geochemistry of ashes: Energy Dispersive X- Ray Spectroscopy (EDX)}

The geochemical characteristics of the ash grains were analyzed in order to establish a classification and to be used as a tool to distinguish between juvenile and non-juvenile grains. Therefore, the analysis focused on the identification of altered components on the surface of the grains and the general geochemical classification of fragments, which may indicate either an origin from a common source or a polymictic character of the bulk of the ash. Results of the quantitative compositional analysis of the studied grains are shown in table 1 .

\section{Coated Samples}

Volatile and soluble elements of the ash are expected to be lost by sifting the ashes with water. Therefore, a batch of non-rinsed ash was analyzed using EDX in order to establish the presence of certain elements in the volcanic dust. To center the analysis on the dust, point scans were performed by focusing the electron beam on individual fine particles coating the coarse grains rather than performing a bulk analysis. The dust particles were identified by increasing the magnification of the SEM image. The elements that stood out on the non-rinsed grains were chlorine and arsenic. Figure 5 shows the spectrogram for the composition of the coating of grain "LQf2" from the October 29, 2014 Turrialba eruption.

The spectrogram shows the presence of peaks corresponding to the element arsenic at approximately $1.2 \mathrm{keV}$ and chlorine at approximately $0.3 \mathrm{keV}$ and a multiple at $2.7 \mathrm{keV}$. These elements are absent on the rinsed samples, which may indicate that they are associated with the dust fractions or that they are coating the coarser grains and have been removed by the processing of the sample. According to Mahimairaja et al. (2005), geogenic arsenic is present at a mean concentration of $1.5-3.0 \mathrm{mg} / \mathrm{kg}$ in igneous rocks but may occur at higher concentrations in groundwater $(3.8 \mathrm{mg} / \mathrm{kg})$ due to the input of geothermal sources. Volcanic ash may also contain high concentrations of arsenic due to its high content of volcanic glass which has a range of concentration of arsenic between $2.2-12.2 \mathrm{mg} /$ $\mathrm{kg}$, according to Smedley \& Kinniburgh (2002).

Quantitative analysis of the clay coating of grain LQf2 showed, as shown in table 1, an anomalously high content of $\mathrm{As}_{2} \mathrm{O}_{5}$ at $0.491 \mathrm{wt} . \%$. This is equivalent to $4910 \mathrm{mg} / \mathrm{kg}$. This is two orders of magnitude above the upper limit reported by Smedley \& Kinniburgh (2002) for volcanic glass. Such a high concentration may be the result of enrichment by the hydrothermal system or supergene enrichment due to the alteration of glass. Quantitative results may also be skewed by performing a point analysis that could have been focused on an arsenic rich particle, rather than on a representative bulk of the clay fraction. However, a representative bulk analysis in the case of the clay fraction is difficult to perform due to particle size and distribution.

The presence of these elements, especially arsenic, is of environmental importance since they pose a risk due to their toxicity (Roy \& Saha, 2002). The fact that arsenic is leachable in water due to its mobility at $\mathrm{pH}$ values that are common for groundwater --pH 6.5-8.5 according to Smedley \& Kinniburgh (2002)--, indicates that there could potentially be contamination of ground and surface water due to the dispersion of ashes. The environmental effects of the soluble contents of the ashes must be further studied if Turrialba activity is sustained over a significant period.

\section{Clean samples}

The chemical composition of the clean samples was analyzed in order to establish the origin of the ashes and distinguish between juvenile and non-juvenile components. Figure 6 shows the spectrograms obtained for several ash grains and the un-normalized concentration in weight percentage for each of the elements identified from the spectrogram peaks. Grain "LSBm2" was collected from "La Silvia" site after the October 29, 2014 eruption. This grain is a porphyritic, nonjuvenile lithic clast. Its spectrogram (Fig. 6A) shows the presence of common rock-forming elements: $\mathrm{Na}, \mathrm{Mg}, \mathrm{Al}, \mathrm{Si}, \mathrm{K}, \mathrm{Ca}, \mathrm{Ti}$, and $\mathrm{Fe}$, as well 


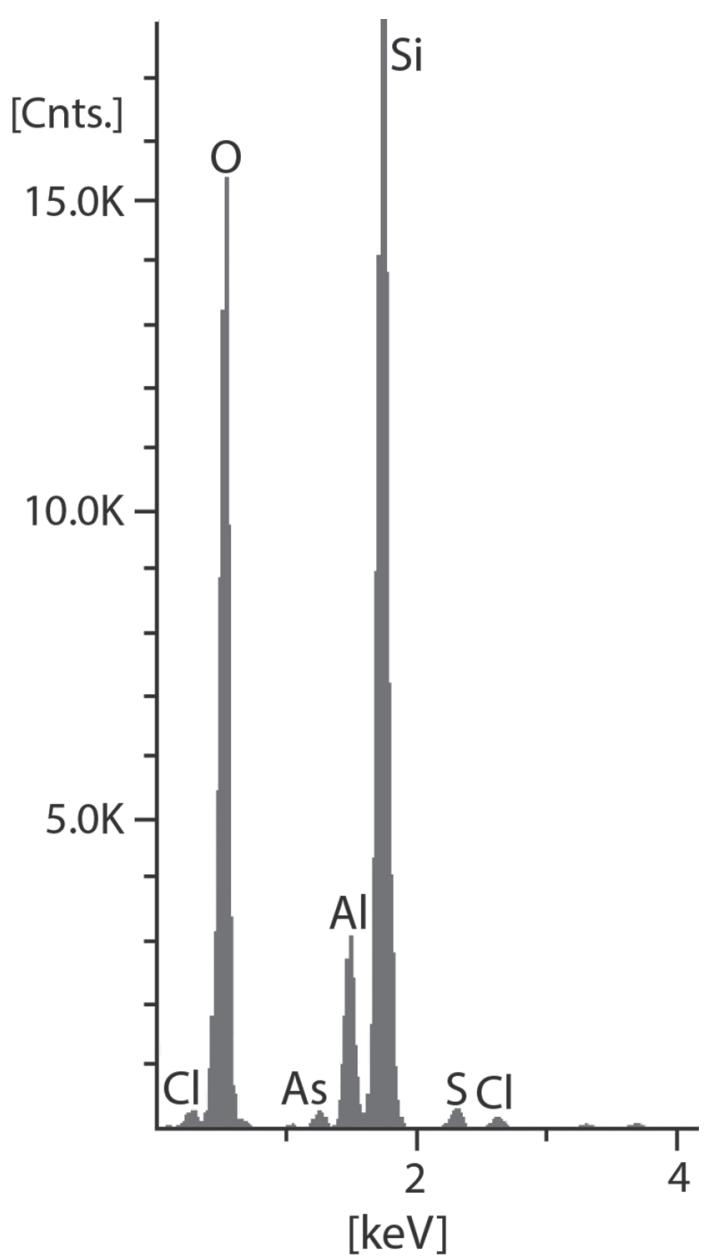

Fig. 5: Spectrum from elemental analysis by means of Energy Dispersive X-Ray Spectroscopy (EDX). Analysis on the dust coating of a non-rinsed (coated) ash grain (code LQf2) from the October 29 eruption shows the presence of a peak corresponding to the element arsenic (As) at approximately $1.2 \mathrm{keV}$.

as sulphur, that may be present as remnant coating in native form or bound to another element such as iron, forming pyrite due to hydrothermal alteration.

Grain A5 is a tachylitic scoria from the March 12,2015 eruption collected near the active crater. Its spectrum (Fig. 6B) shows the presence of the elements: $\mathrm{Na}, \mathrm{Mg}, \mathrm{Al}, \mathrm{Si}, \mathrm{K}, \mathrm{Ca}, \mathrm{Ti}$, and Fe. The spectrum in figure $6 \mathrm{C}$ corresponds to grain $\mathrm{C} 1$, an olivine free crystal from the March 12, 2015 eruption. The spectrum shows the presence of the elements: $\mathrm{Na}, \mathrm{Mg}, \mathrm{Al}, \mathrm{Si}, \mathrm{K}, \mathrm{Ca}$, and Fe. This particular spectrum is comparable to the spectrum presented by (Reed, 2006) for the Montecellite variety of olivine due to the appearance of calcium. The presence of $\mathrm{Al}$ and $\mathrm{Na}$ may be due to residual glass attached to the surface of the crystal that may not be visible under optical microscopy. The spectrum in figure 6D corresponds to a plagioclase crystal and shows, as expected, the presence of the elements: $\mathrm{Na}, \mathrm{Al}, \mathrm{Si}$, and $\mathrm{Ca}$. Because of the anorthite content (An 61\%), this plagioclase is classified as Labradorite. All spectra show an oxygen peak at approximately $0.3 \mathrm{KeV}$ (Figs. 5 and 6). Although the presence of oxygen is determined qualitatively from the appearance of this peak, the concentration of oxygen cannot be quantitatively analyzed with the available EDX equipment. For this reason, the elemental concentration shown in figure 6 was stoichiometrically converted into oxides, presented in table 1.

A compositional analysis of the ash grains was carried out in order to geochemically characterize the source of the grains. Free crystals aside, individual grains were analyzed and classified by rock type (Fig. 7) using the TAS diagram (LeBas et al., 1986) based on the quantitative composition obtained from EDX. For the 2014 eruptions, EDX analysis was performed on pumice grains, porphyritic lithics, tachylithic scoria, and vesiculated sideromelane grains. Overall, the grains from this eruptive period show an erratic and broad distribution in composition, from basalt to rhyolite. This clear polymictic composition of the ashes from 2014 indicates that the grains do not share a common source, and it is further evidence that the ash is the product of the fragmentation of previous material dispersed as non-juvenile tephra by a phreatic eruption. Some grains exceed the silica content expected for normal rock types. This anomalously high silica content suggests that secondary $\mathrm{SiO}_{2}$ may have been introduced by the hydrothermal system. This silicification is a clear criterion for the classification of grains as non-juvenile.

Concerning the March 12, 2015 eruption, the non-juvenile grains show compositional characteristics similar to the 2014 ash. However, the grains of tachylithic scoria and vesiculated sideromelane that were considered as the juvenile fraction of the ash for this eruption (squares in figure 7), show a narrow distribution in composition ranging from 

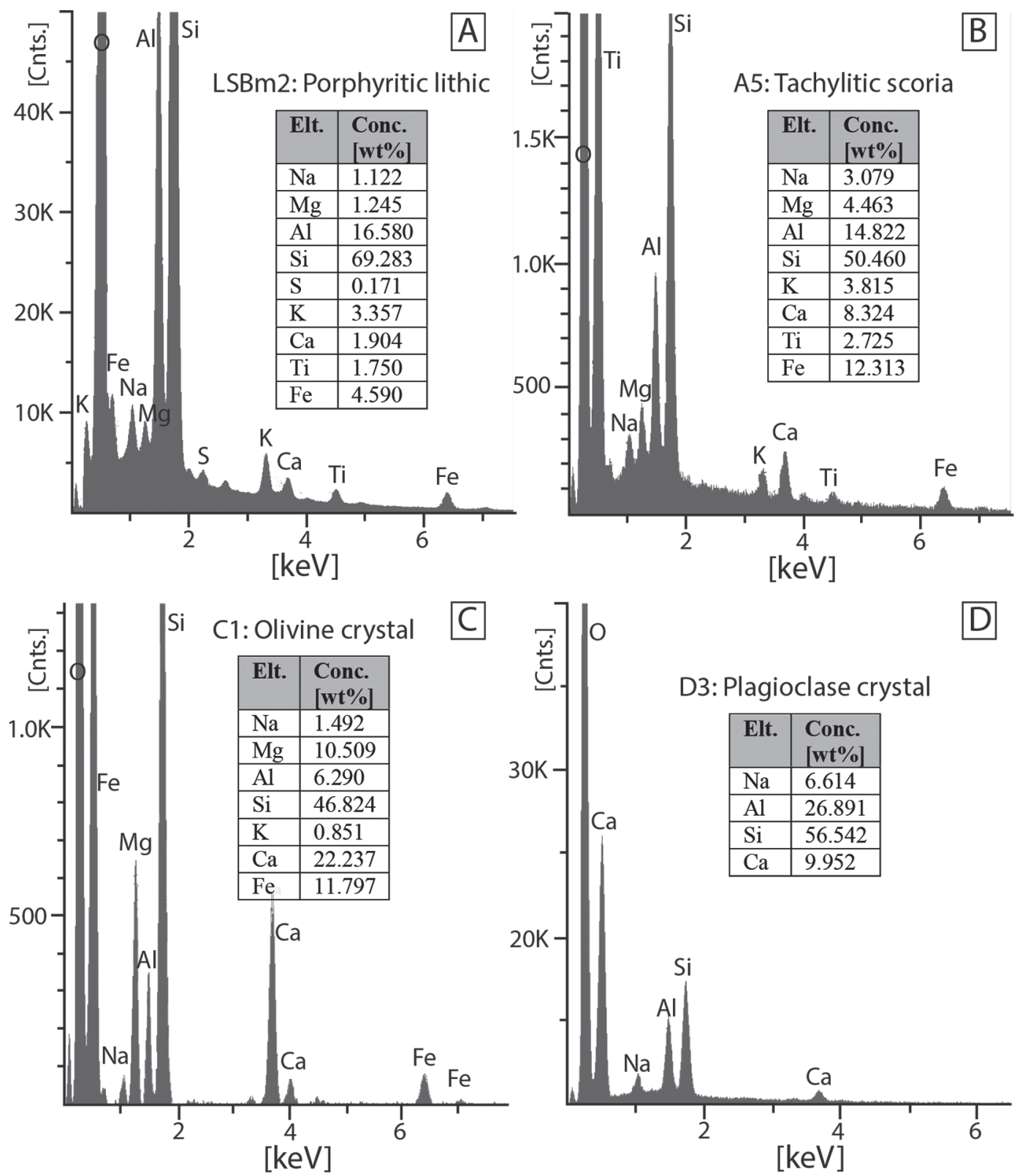

Fig. 6: Spectra from elemental analysis by means of Energy Dispersive X-Ray Spectroscopy (EDX). A) EDX spectrum for a clean grain from the October 29, 2015 eruption. Note the absence of the arsenic peak present in figure 5. B) EDX spectrum for the clean ash grain from the March 12, 2015 eruption shown in figure 4A. C) EDX spectrum for the olivine free crystal from the March 12, 2015 eruption shown in figure 4E. D) EDX spectrum for the plagioclase free crystal from the March 12, 2015 eruption shown in figure 4G.

andesite to dacite with silica contents between approximately 58 and $62 \mathrm{wt} . \%$. The narrow variation in composition suggests that these grains may share a magmatic source. The absence of silicification indicates that prolonged exposure to the hydrothermal system did not occur on these grains. The geochemical characteristics of the aforementioned grains support the observations 


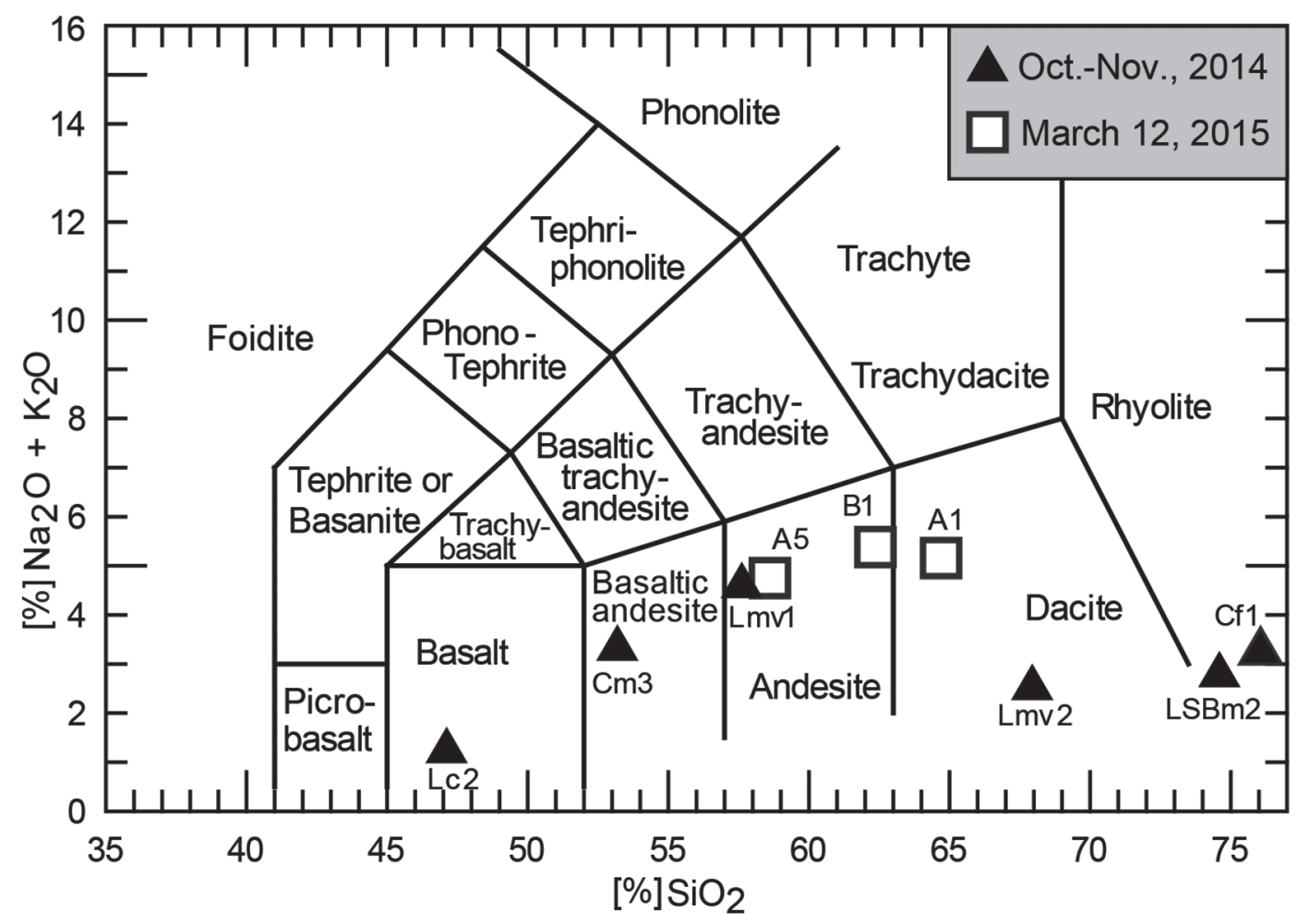

Fig. 7: Classification of individual ash grains based on total alkali vs. silica diagram by (LeBas et al., 1986).

from optical microscopy and SEM images and the interpretation of the presence of juvenile fragments on the ashes of the March 12, 2015 eruption.

\section{CONCLUSIONS}

The ashes from the October 29 - November 1, 2014 Turrialba eruptions show no presence of juvenile components. Non-juvenile components identified in the $2.7 \phi$ fraction of the ashes are: altered sideromelane, altered tachylitic scoria, hydrothermally altered lithics, altered plagioclase crystals, sulphur and gypsum crystals. The absence of juvenile fragments indicates that these eruptions were the product of fragmentation of pre-existing material by means of explosive expansion of gases, mainly water vapor. In this case, since all ejecta are composed of pre-existing rock, magma may only have played a role as a source of thermal energy by heating and flashing water, as stated by Browne \& Lawless (2001), and not as a contributor of solids. This indicates, according to Barberi et al. (1992), that these eruptions were phreatic events.

The ashes from the March 12, 2015 Turrialba eruptions show the presence of both juvenile $(\sim 24$ wt.\%) and non-juvenile ( 76 wt.\%) fragments. The juvenile fragments in the form of unaltered tachylitic scoria, vitreous sideromelane, and olivine and plagioclase free crystals indicate that the eruptions were of phreatomagmatic origin. In this case, magma is directly involved as a source of ejected mass and not only as a source of energy for the fragmentation. Thus, as stated by Browne \& Lawless (2001), the ejection of any juvenile igneous material should lead to a classification of this event as a phreatomagmatic eruption. 
Overall, the non-juvenile fractions of the ashes show a clear polymictic composition ranging from basalt to rhyolite. Anomalous silica contents on pumice grains and lithics are attributed to silicification processes through the hydrothermal system. The juvenile tachylite and sideromelane grains of the ashes from the March 12 eruptions show an andesitic/dacitic composition, whereas free crystals of olivine and calcium rich plagioclase hint at a more mafic magmatic source. The intermediate composition of the vesiculated grains may be skewed by higher silica contents due to the analysis being performed on predominantly glassy particles.

The samples of the ashes submitted to the SEM analysis without previous rinsing show a peak in the EDX spectrum corresponding to the element arsenic. This peak is absent in the samples that were separated from the dust fractions. This suggests that arsenic may be present in the dust fraction of the ash. This fraction is the product of chemical fragmentation of pre-existing rock by interaction with the hydrothermal system; this non-juvenile material may be enriched in As due to pervasive hydrothermal alteration. Since arsenic is considered highly mobile, the absence of the rinsed samples from the surface may be a result of lixiviation. However, it can be concluded that no arsenic is present imbedded in the matrix of the $2.7 \phi$ samples.

\section{ACKNOWLEDGEMENTS}

The authors sincerely acknowledge the help of colleagues from the Red Sismológica Nacional (RSN, UCR-ICE) in the collection of some of the samples, as well as the help of the RSN with the funding of the SEM analysis sessions. We acknowledge the contribution of CIEMic and thank them for their support of geoscience research. Special thanks to Paula Calderón, whose time and expertise allowed us to take full advantage of the SEM sessions. We thank W. Pérez for her comments, which contributed to the improvement of the original manuscript. This article is a contribution to research project 113-B5-A00 entitled: "Geofísica y geodinámica interna del arco volcánico en Costa Rica", from the University of Costa Rica.

\section{REFERENCES}

Instituto Nacional de Estadística y Censos (INEC), 2011: X Censo Nacional de Poblacióny VI de Vivienda: Resultados Generales.INEC. San José.- 140 pp. INEC, San José [Tech. Rep.].

BARBERI, F., BERTAGNINI, A., LANDI, P. \& PRINCIPE, C., 1992: A review on phreatic eruptions and their precursors.- J. Volcanol. Geothermal Res. 52(1992): 231-246, DOI: 10.1016/0377-0273(92)90046-g

BRAGADO-MASSA, E., MARCHAMALO, M., REJAS, J. G., BONATTI, J., MARTÍNEZFRÍAS, J. \& MARTÍNEZ, R., 2014: Monitoring Hydrothermal alteration in active volcanoes using remote sensing: the case of Turrialba Volcano (Costa Rica).Rev. Geol. Amér. Central, 51: 69-82, DOI: 10.15517/rgac.v51i1.16848

BROWNE, P. R. L. \& LAWLESS, J. V., 2001: Characteristics of hydrothermal eruptions, with examples from New Zealand and elsewhere.- Earth-Science Rev. 52(4): 299-331, DOI: 10.1016/s00128252(00)00030-1.

CARR, M. J., 2014: Igpet for Windows.- 64 pp. Terra Softa Inc., Somerset, New Jersey.

LEBAS, M. J., LEMAITRE, R. W., STRECKEISEN, A. \& ZANETTIN, B., 1986: A chemical classification of volcanic rocks based on the total alkali-silica 
diagram.- J. Petrol. 27: 745-750, DOI: 10.1093/petrology/27.3.745.

MAHIMAIRAJA, S., BOLAN, N. S., ADRIANO, D. C. \& ROBINSON, B., 2005: Arsenic contamination and its risk management in complex environmental settings.Advances in Agronomy, 86: 1-82, DOI: 10.1016/s0065-2113(05)86001-8.

PARDO, N., CRONIN, S. J., NÉMETH, K., BRENNA, M., SCHIPPER, C. I., BREARD, E., WHITE, J. D. L., PROCTER, J., STEWART, B., AGUSTÍNFLORES, J., MOEBIS, A., ZERNACK, A., KERESZTURI, G., LUBE, G., AUER, A., NEALL, V. \& WALLACE, C., 2014: Perils in distinguishing phreatic from phreatomagmatic ash; insights into the eruption mechanisms of the 6 August 2012 Mt. Tongariro eruption, New Zealand.- J. Volcanol. Geothermal Res. 286(2014): 397-414, DOI: 10.1016/j.jvolgeores.2014.05.001

REAGAN, M. K., DUARTE, E., SOTO, G. J. \& FERNANDEZ, E., 2006: The eruptive history of Turrialba volcano, Costa Rica, and potential implication hazard from future eruptions.Geol. Soc. Amer. Spec. Paper, 412: 235-257.

RECIO, P., 2015: Aeropuerto Juan Santamaría permanece cerrado hasta este viernes a las 8 a.m.- La Nación [online], http:// www.nacion.com/nacional/transportes/ Cierran-Aeropuerto-Juan-Santamariaceniza_0_1474852642.html [Consulted: 21 July, 2015].

REED, S. J. B., 2006: Electron Microprobe Analysis and Scanning Electron
Microscopy in Geology.- 192 pp. Cambridge University Press, United Kingdom.

ROUWET, D., SANDRI, L., MARZOCCHI, W., GOTTSMANN, J., SELVA, J., TONINI, R. \& PAPALE, P., 2014: Recognizing and tracking volcanic hazards related to nonmagmatic unrest: a review.- J. Applied Volcanol. 3(17): 1-17, DOI: 10.1186/ s13617-014-0017-3

ROY, P. \& SAHA, A., 2002: Metabolism and toxicity of arsenic: A human carcinogen.Current Sci. 82(1): 38-45.

RUÍZ, P., 2012: Reconstruction of the paleo and neo stages of Poás and Turrialba volcanoes, Costa Rica: Competing processes of growth and destruction.- 174 págs. Rutgers University, New Brunswick, New Jersey [Tesis Ph.D].

SMEDLEY, P. \& KINNIBURGH, D., 2002: A review of the source, behaviour and distribution of arsenic in natural waters.- Applied Geochem. 17(5): 517-568.

SOTO, G. J., 1988: Geología y vulcanología del volcán Turrialba, Costa Rica.Costa Rican Volcanism Workshop, Washington, D.C. and Shenandoah National Park: 18.

SOTO, G. J. \& MORA, M., 2012: Actividad del volcán Turrialba en el periodo 20072011 y perspectivas de su amenaza.- In: ADAMSON, M. \& CASTILLO, F. (eds): Desastres: Costa Rica en el tercer milenio desafíos y propuestas para la reducción de vulnerabilidad.- Contrastes Vivos de Costa Rica, San José: 287-310. 
